\title{
VIEWPOINTS
}

\section{Afghanistan's Peace Talks Stalling for Lack of Initiative}

\author{
Mohammad Hashim Kamali*
}

In recent months Kabul, Washington and the Taliban have made overtures to work out a negotiated settlement for Afghanistan and plan the impending exit of foreign troops from the country. Yet those gestures have not been followed through and the prospects are not getting any better - as the spate of recent violent episodes and perverted behaviour of some US soldiers over the war dead have shown. Time is running out and any further episodes will exacerbate the tension that flared up with the Qur'ān burning, the March 2012 massacre of 17 civilians, and the most daring Taliban attack on 15 April 2012 of five locations in as many provinces. Washington wants to plan an orderly exit from Afghanistan, secure agreements to curb terrorism further escalating, and plan for an orderly election. All three parties seem to share these objectives. The Taliban have been decimated and it seems have also changed their initial position to negotiate only after the exit of the foreign forces from Afghanistan. They seem to have realised that negotiating with Kabul is not fruitful and that talking to the Americans, especially in the wake of their exit plan, is the course they now want to take - hence the Taliban request to open a political office in Qatar. This is in the interest also of Kabul and Washington as only then would they all know with whom to talk. For the Taliban are not a monolithic voice, and new commanders have emerged on both sides of the border with Pakistan, not all of whom are speaking the same language.

Kabul has conceded, after some hesitation, to the Taliban demand to have a representative office in Qatar - in preference apparently to Turkey, which is a NATO member, and even Saudi Arabia, which was mentioned but not agreed to. Washington has also conceded to the release of some of the Taliban leaders from Guantanamo far fewer, it seems than what the Taliban are asking for, with the proviso also for a US veto power over the choice of names. The Taliban have also requested that the Black List, which has made travel difficult for them, be rescinded. What has transpired so far is thus indicative of a willingness to negotiate.

The recent US-Kabul deal that the nefarious night raids should henceforth be governed by Afghan law is also indicative of a concessionary stance. Much would still depend on Washington's willingness to give this due credibility and let the rule of law control these particularly objectionable raids.

* Mohammad Hashim Kamali is the Chairman and CEO of IAIS Malaysia. An earlier version appeared on 2 May 2012 in The New Straits Times (Kuala Lumpur). 
The Taliban have, furthermore, adjusted their earlier views concerning, for instance, female education. In a recent talk at IAIS in Kuala Lumpur, Mulla Zaeef, a former Taliban leader, asserted that the Taliban were not against female education but wanted to regulate it in accordance with Islam and Afghan traditions and that they were open to power sharing and not against democracy. The fact that the Taliban, when in power, were besieged and boycotted by the world community invoked certain exaggerated responses from them. A consensus seems to be emerging, it was added, over the failure of the military approach, and there was, therefore, no other alternative to peace talks. The general concern now is over the prospects of how and under what conditions the American military are likely to leave Afghanistan.

Failing a negotiated settlement for military disengagement, violence is not only likely to continue but to escalate further. The so-called Spring Offensive, as recently announced by the US military headquarters in Kabul, is particularly inopportune, and should be withdrawn, if the proposed talks are to have a chance. It is far better, even for the Americans, to bind the Taliban to a plan for a ceasefire now, secure overall commitments to reduce violence - and pave the way for a more comprehensive political settlement later.

The issue of US military bases and last November's 'Traditional Loya Jirgah' (TLJ, 'grand council') decision on a long-term strategic plan concerning the issue remains problematic. The manner of convening the TLJ and its endorsement of such a momentous decision, without the involvement even of the sitting Parliament, have remained controversial. There was no public debate on this and no clear information of its details. Following the March massacre, Karzai announced that a careful scrutiny of the military bases issue would be undertaken. It seems that the USKarzai agreement over the bases has involved, not just one, but five bases in as many provinces of Afghanistan.

\section{Recommendations}

- Confidence building measures are needed now to put fresh impetus to the stalling peace talks. This may involve a clear indication of interest, especially by the Americans, in peace negotiations.

- Further clarification over the military bases issue is also needed as the assumption would hold otherwise that the US is planning a long-term stay in Afghanistan, which is seen as a recipe for continued conflict. If indeed there is an agreement over this, it should be subjected to the normal legal process for ratification of international treatises, preferably after the exit of occupation forces. If the US withdrawal means that it still maintains forces in the order of the rumoured 20,000 soldiers, this is likely to be contentious, unless a further phasing out is also made a part of the plan. 
- Moreover, the present Afghan army is ethnically-based and marginalises the Pashtun majority. This is still a US-backed policy, which is, however, deeply problematic and should be changed, if one were to entertain the prospects of handing over the country's security and defence to the Afghan army.

- No stable political future for Afghanistan can work without Pashtun participation, and must in any case be based on fair participation of all ethnic, religious and political segments of the Afghan populace.

- A clear change of policy on this will be seen as a confidence-building measure and help toward planning a sustainable political future for Afghanistan. 